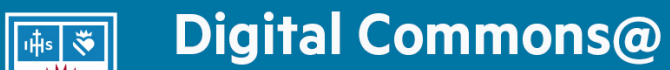

Loyola Marymount University

LMU Loyola Law School

\section{Journal of Catholic Education}

$12-2021$

\section{Catholic Education and the Idea of Curriculum}

\author{
Leonardo Franchi \\ University of Glasgow \\ Robert Davis \\ University of Glasgow
}

Follow this and additional works at: https://digitalcommons.Imu.edu/ce

Part of the Curriculum and Instruction Commons, Liberal Studies Commons, Social and Philosophical Foundations of Education Commons, and the Teacher Education and Professional Development

Commons

\section{Recommended Citation}

Franchi, L., \& Davis, R. (2021). Catholic Education and the Idea of Curriculum. Journal of Catholic Education, 24 (2). http://dx.doi.org/10.15365/joce.2402062021

This Article is brought to you for free with open access by the School of Education at Digital Commons at Loyola Marymount University and Loyola Law School. It has been accepted for publication in Journal of Catholic Education by the journal's editorial board and has been published on the web by an authorized administrator of Digital Commons at Loyola Marymount University and Loyola Law School. For more information about Digital Commons, please contact digitalcommons@lmu.edu. To contact the editorial board of Journal of Catholic Education, please email JCE@nd.edu. 
Journal of Catholic Education

Fall 2021, Volume 24, Issue 2, 104-119

This work is licensed under CC BY 4.o. (c) (P)

https://doi.org/10.15365/joce.2402062021

\title{
Catholic Education and the Idea of Curriculum
}

\section{Robert Davis, Ph.D. ${ }^{1}$ and Leonardo Franchi, Ph.D. ${ }^{1}$}

\begin{abstract}
Critical reflection on the curriculum offered in the Catholic school is a valuable addition to wider dialogue on the nature of education and schooling. It enables the Church's educational agencies to offer a distinctive vision of education to the diverse range of students who freely participate in its educational ventures. In Catholic thinking, education is the study of humanity and its achievements. The curriculum of the Catholic school speaks to internal and external audiences and is a bridge uniting the Catholic worldview with other intellectual traditions.
\end{abstract}

Keywords: curriculum, liturgy, identity, dialogue, Catholic education

$\mathrm{T}$ he recent turn in Catholic education toward the explicit embrace of intercultural dialogue in the Catholic school demands some imaginative responses by those committed to developing the mission of Catholic education (Congregation for Catholic Education, 2013; McDonough,

2018). The new dialogue involves a refocusing of the mission of the Catholic school, and should encourage serious reflection on what it means to be a Catholic school today. This applies equally to schools located in countries with a long Catholic heritage as well as to countries shaped by the $16^{\text {th }}$ century Reformation. Given the many sociocultural and political pressures faced by Catholic educational institutions in the current climate, does a commitment to intercultural dialogue mean solely that the Catholic school must be open to other worldviews? Or can it also mean that Catholic educators have a duty to propose the educational principles underpinning Catholic education to a wider constituency?

In framing a suitable response to such complex, necessary, and vital questions, it is important to focus on the nature of the curriculum offered in Catholic schools. The authors argue that there

1 University of Glasgow

https://orcid.org/oooo-0003-0646-0975, https:/orcid.org/oooo-0oo2-5067-7357 
is such a thing as a Catholic understanding of curriculum and that a reclamation of this insight offers Catholic schools an opportunity to review and reform their provision of an inclusive yet distinctive education (Sullivan, 2001). Furthermore, a refreshed examination of the potential of a Catholic understanding of the curriculum to contribute meaningfully to both external and internal debates on the nature of education is pressing. While the subject of religious education is often proposed (with some justification) as providing the "core" of the Catholic school's characteristic identity, it cannot-and should not-be seen as the single repository of the distinctive culture of the school (Congregation for Catholic Education, 1988).

A shared understanding of terminology, of course, is important. "Catholic Curriculum," as employed in the present article, is shorthand for the distinctive course of studies available in a Catholic educational institution. This has implications for how individual subjects are framed and presented as windows into a created and evolving world, understood in light of the Incarnation. The Catholic Curriculum, to be clear, is powered by the union of faith and reason, focuses on embedding skills in knowledge and encourages students to live a life of wisdom and discernment. This is similar to broader wisdom traditions in education but, crucially, defines wisdom as the Logos-the Word of God: It is a universal invitation to critically explore the best of humanity, as expressed for example in the arts and sciences.

A Catholic Curriculum, therefore, requires prior disposition toward the Catholic intellectual tradition and a commitment to ensuring that the insights of that tradition are given sufficient space in the curricular offerings of the school. Building upon previous and ongoing analysis of the question, we will argue for a prior stage of formation, awareness-raising, reflection, and collegial deliberation anterior but fundamental to the task of curriculum or syllabus design. Yes, there are important implications in what we propose for the means and methods of curriculum design in Catholic schools that are committed to their own and the common good. We highlight sources of inspiration, guidance, and motivation that are often, we believe, overlooked by today's planners and pedagogues: not through negligence or hostility, but in consequence of the largescale centralized forces of educational competition and change with which they must contendalongside an accompanying tacit attenuation of what constitutes the modern curriculum and its educational objectives. It is to this stage of curriculum-making that our ideas and interventions are devoted (Priestley et al., 2021).

In this task, we act and write in continuity with some 20 years of renewed thinking-and indeed fruitful staff development-on the concept of the Catholic Curriculum, including contributions made by the present authors (Arthur \& Walsh, 2007; Davis, 1999; Davis \& Franchi, 2013). A strong value in this body of work has been a clearly demarcated respect for the authority, practices, and knowledge of professional practitioners and leaders responsible for the design and implementation of core curriculum content within diverse and dynamic educational systems across the globe. We 
here reiterate this respect for boundaries and principles of collaborative working, and thus eschew throughout this essay the "prescription" of an imagined confessionally compliant content for the disciplines of daily learning in the Catholic (or any other) school. This is not our purpose or our responsibility, and the reader will find here no Catholic syllabus for teaching fractions, French grammar, or the causes of the First World War. While there are published examples of how to understand and communicate Catholic intellectual traditions in education (Franchi et al., 2021; Rausch, 2012)-both edited volumes take individual subject areas and show what it could mean to frame them for the Catholic educational institution-the actual curricular content is a matter for local discussion and agreement.

In Part 1, we propose that the aim of the Catholic Curriculum is to contribute toward the rebuilding of the culture of the contemporary Catholic school. In Part 2, we show how a Catholic Curriculum supports a view of education as a liberal and civilizing force for the whole of society.

\section{Part 1: Rebuilding the Culture of the Catholic School}

To rebuild its educational culture, the Catholic school needs: (a) a curriculum rooted in a Catholic philosophy of education; (b) a message which is incarnated in the life of the school, and, (c) a corps of teachers with the capacity to shape and share the vision in their local contexts.

\section{Catholic Philosophy of Education as the Basis of the Curriculum}

Central to the argument of the present article is the desire to articulate a coherent curriculum framework to underpin and enhance the mission of the Catholic school. As part of this essential drive for clarity, we begin by acknowledging fully the importance of gathering suitable empirical data on the various metrics which are part of national and international discussions on school effectiveness. Catholic schools are not immune from the need to move in this atmosphere of accountability and openness to public critique: As civic institutions, often with a religiously diverse intake, it follows that they should be subject to the same level of scrutiny as that faced by other forms of schooling - while playing a full part in wider, and often necessarily critical, discussions about the level and types of scrutiny to which schools should legitimately be subject.

Nonetheless, there is a prior need to develop firm foundations for the life of the Catholic school, whether it be located in a public or private system. Catholic schools, colleges, universities, and seminaries are the visible expressions of the Catholic Church's commitment to educate, form, and inform. The openness of contemporary Catholic institutions to people of all religious traditions demands that such bodies have the capacity, as well as the desire, to offer intellectual and cultural hospitality to those who frequent its halls of learning. This direction of travel seems to be wholly in line with high-level and prominent initiatives such as Pope Benedict's Court of the Gentiles (Benedict XVI, 2011) and the commitment by Pope Francis to foster a culture of encounter and dialogue across all aspects of the life of the Church (Francis, 2014). 
As noted above, Catholic schools operate at the heart of many plural and secular systems of education. This sociological reality brings such schools into the full light of public scrutiny. Catholic educators are thus called to make a positive contribution to civic debates on all aspects of education and schooling, not just on issues which have direct or indirect relevance to Catholic school systems. Given this reality, there is a need to develop theories and philosophies of education that extend a Catholic understanding of the world to educational contexts beyond Catholic schools. This approach stands in contrast to research and practice that emphasize the separation of Catholic schools from other systems of education. In other words, the focus of Catholic thinking on education should move from the inside to the outside, placing it on par with philosophies from other educational sectors. It should therefore also move away from a ghettoized mentality with the associated (and regrettable) tendency of some Catholic educators to focus chiefly on the workings (and success) of the Catholic school system as measured by standard metrics. We now consider what this positioning means for the concept of a Catholic Curriculum.

\section{Catholic Curriculum: Incarnating the Message}

To what extent is "Catholic Curriculum" a helpful term, given its semantic and conceptual limitations for those who do not belong to the Catholic religious tradition? We suggest three ways of dealing with this important question.

First, a theological lens can offer a clearer focus to our thinking. The Catholic Curriculum, to be clear, is the fruit of considered and nuanced reflection on the Christian doctrine of the Incarnation (McLaughlin, 2002). God's "taking flesh" divinizes human activity: To be fully human, to flourish as a human being, is to seek and find the good, the true, the beautiful in all people and in all things. Authentic Christianity cannot but repudiate a false (but regrettably not uncommon) dualism of spirit-good/matter-bad: It recognizes the potential of the human person to do good (the "divine spark") but is not blind to our potential to act in ways that fall short of the ideal (the "original sin"). ${ }^{1}$

Second, the Catholic Curriculum, at its best, aims to liberate the human person from the many manifestations of our human weaknesses. It gestures us confidently toward the pinnacles of human achievement and therein offers its participants the possibility of intellectual, religious, and cultural enrichment. Central to this understanding of curriculum is the liberal nature of school studies: the diet of open-ended possibilities for human flourishing that the curriculum offers, which cannot ordinarily be reshaped to fit an agenda that is more suitable for practical-and arguably necessary and appropriate-training programs.

Third, the Catholic Curriculum is an opportunity for genuine dialogue between people of different religious and philosophical traditions. The importance of educational dialogue was

$1 \quad$ For more on this, see Rausch (2012). 
underlined in the early Church by Saint Basil the Great (AD 330-379) whose classic educational text, Address to Young Men on the Right Use of Greek Literature, lays out some parameters of how the Christian could profit from non-Christian texts Padelford (1902). In the seminal medieval epic, The Divine Comedy, we recall that the "pagan" poet Virgil (representing Reason) guided the Catholic poet Dante Alighieri through the theological mazes of Hell and Purgatory, with "Beatrice" (representing Revelation) leading him to heaven (1993). So too the Catholic Curriculum qua curriculum is receptive and responsive to wisdom and insights from all sites of human learning. This disposition, of course, must not translate into a shallow moral relativism which, at its most extreme, was defined by Pope Francis as "ideological colonization" (San Martí, 2017). Rather, it demands that we take concrete steps to learn better how to engage in meaningful dialogue with interlocutors who are not part of our religious tradition and who may pose serious questions for it. The example of Virgil and Dante is not peripheral to what we propose, but is a manifestation of a rich encounter between multi-sourced ideas and their cultural, political, and social ramifications.

Finally, we acknowledge that schools are often located at the crossroads where the flow of political ideology and initiative meets established and longstanding cultural realities, often with uncomfortable consequences. We see this, for example, in current high-level debates about gender and free speech, and enduring philosophical disputes around such topics as free will and determinism (Cole, 2017; Kitchen, 2017). A Catholic Curriculum, therefore, with its commitment to a broad liberal education, is where such dialogue is encouraged, indeed demanded, if it is to be taken seriously. Nonetheless, a commitment to such dialogue itself needs sure foundations if a Catholic Curriculum is to be of enduring value and not just represent a particular inflexion of the ideologies currently in vogue. The key actor in this endeavor is the teacher.

\section{The Educated Teacher}

It is in the person of the teacher that we encounter the intersection of inherited culture and contemporary creativity. Teachers are not, and cannot be, passive bystanders on the road to knowledge but shape the educational journey because they are (we trust) agents with substantial levels of subject and pedagogical expertise. This is not to denigrate the role teachers can often play as facilitators of student learning, far from it; but is a recognition that even successful facilitation, so to speak, requires a suitably deep understanding of the subject matter (Kadir, 2017). The educated teacher-the living link between inherited traditions and the hopes and aspirations of current generations-must be both conservative/traditional and liberal/progressive: going beyond

politically charged labels and transient false dichotomies while seeking to educate the person to be a free and flourishing individual-in-community. This is indeed a tall order and requires serious thinking on how such aspirations can be met.

We learn from Saint Augustine of Hippo that the teacher's primary duty is to point to the 
Truth (i.e., Jesus; Augustine, 1995). In order to carry out this important activity, the teacher needs an intellectual, cultural, and pastoral formation of (Rymarz \& Franchi, 2019) sufficient rigor to allow this duty to be performed with the appropriate levels of knowledge, (DarlingHammond, 2017) kinds of skill, and fundamental dispositions of character (Rymarz \& Franchi, 2019). Teacher development is (rightly) a priority in the rapidly advancing world of modern education. (Darling-Hammond, 2017). In addition, there is an increasing awareness of the importance of educational leadership and of the need to create a continuum of support, both before and after initial qualification, (Warren, 2021). To foster this pedagogical excellence, however, it is important to shift the language of the prevailing discourse. We argue for "educated educators," not simply "qualified teachers." The development of a corps of suitably "educated educators," with rich cultural hinterlands informing and shaping their mission and understanding of the human condition, is central to any move to reform schools today. A fortiori, this aspiration applies to the Catholic Curriculum because the Catholic tradition reminds us that the teacher is central to the success of the total educational endeavor. As such, the Catholic Curriculum demands that educators are themselves advocates, beneficiaries, and practitioners of a fully liberal approach to education and are committed to contributing to wider public debates in support of such an aim.

\section{Part 2: Curriculum as a Liberal and Civilizing Force}

In Part 2, we argue that for the Catholic Curriculum to be a liberal and civilizing force, it needs: (a) a re-examination of its purpose; (b) a recovery of education as preparation for leisure, not just for work; (c) a refreshed vision of the curriculum as a journey through domains of knowledge, and (d) a recovery of the link between liturgy and education.

\section{Purpose of the Catholic Curriculum}

An understanding of the purpose of a curriculum emerges from considered reflection on the wide avenues represented by the Catholic intellectual tradition (Royal, 2015). How can a curriculum lead us to God? We argue that it can-through imagination, through knowledge, and through action.

\section{To God Through the Imagination}

In an era of both hyper-specialization and often ersatz and inflated interdisciplinary expectations laid upon schools, the Catholic Curriculum must commence from an integral and coherent understanding of the human imagination and the means by which its powers are cultivated. This entails sponsoring a vision of the curriculum where the sources and drivers of the established disciplines call forth from teachers and learners a desire to extend human capacity, enrich understanding, foster moral sentiment, and nurture a sympathetic engagement with reality in its integrated entirety. Across the subjects of the school timetable-in even their most attenuated 
and technocratic contemporary forms-there endures the fundamental appreciation that cognition and application must be underpinned by motivations such as curiosity, wonder, and the excitement of authentic discovery. Traditionally, in liberal conceptions of schooling, the development of these specific faculties was entrusted to the arts-especially literature, music, the fine arts, and performance. A refurbished vision of the Catholic Curriculum today will continue to prize and showcase these disciplinary responsibilities. There is abundant and renewed scope within many current conceptions of the curriculum for preserving and enhancing such an approach (Takaya, 2018). However, when we speak of a holistic conception of the Catholic Curriculum, we intend to radicalize this idea by identifying it much more closely with fundamental dispositions of the human heart and mind, which span the full roster of timetabled disciplines beyond the customary aesthetic silos of, for example, music and art. As such, the deliberate development of a "Catholic imagination" in young learners and their teachers extends to the encounter with the divine in the natural and life sciences; the realms of commerce and enterprise; the interlocking spheres of the ecosystem; the engagement with community and identity through social and environmental studies; and the strengthening of health and wellbeing for the individual person and the group.

\section{To God Through Imagination}

Central to this kindling of the learner's imagination as a prerequisite for an effective curriculum is the question of knowledge. Here, the impulses driving the curriculum in Catholic schools intersect with wider debates and controversies in contemporary education (Organisation for Economic Co-operation and Development [OECD], 2020). It is not the intention of this essay to become snagged in these. However, the preservation, curation, transmission, and renewal of distinct and hallowed bodies of disciplinary knowledge have been historic obligations of Catholic schools since their origins. Commitment to these principles, therefore, does take encouragement from the renewed interest in ideas in schools, such as direct instruction, teacher expertise, and memorization, commonly referred to as "learning by heart" (Blake et al., 1998). Of course, decadent and sterile expressions of these do exist, to the detriment of some schools and their students. As well as this, Catholic education has long recognized that expertise can be acquired, refreshed, produced, and misused in multiple ways and from diverse points of departure. Nevertheless, a Catholic theory of knowledge and rationality, moved and inspired by the workings of divine grace, is rightly skeptical of moves to downgrade narrative knowledge or to collapse it into generic models represented by headings such as "core skills" and "critical thinking." The relationship between knowledge and reason fully entails in Catholic belief the exercise of informed critique and powers of judgment set within a structure of shared authority and collegial deliberation and renewal. On the basis of this essentially moral conception of knowledge and the purposes it serves, the Catholic Curriculum is where such knowledge is valued as the ground of human wisdom, progress, and justice. 


\section{To God Through Action}

Positive perceptions and evaluations of Catholic schools in the modern world often proceed from a favorable appreciation of their contribution to the common good. Even in the most secular polities, Catholic schools are routinely praised for their ethos, commitment to excellence, and works of charity even by those who, philosophically, would be opposed to religious schooling. There are public figures who have expressed support for Catholic schools in a public system of education, even if likely opposed in principle to faith-based schooling (e.g., First Minister of Scotland Nicola Sturgeon; see Sturgeon, 2018). A distinctly Catholic philosophy of education affirms all of this but insists that its impetus lies in the expression of a culture of faith founded on a distinctive Christian anthropology, which demands a commitment to the promotion of human flourishing and dignity. Every "action" of the Catholic school in the world-be it in the fields of climate change or financial responsibility, or the works of charity at home and abroad-serves these same ends, and draws its vitality from an understanding that is empowered by the empathetic imagination and grounded in authentic knowledge and reasoning. Developing an ethos of action and intervention in the created world is integral to both the formation of the human person as a reflection of the divine and the fashioning of a community vested in the witness of the gospel.

\section{Educating for Leisure}

To reiterate: In setting out the parameters of a Catholic Curriculum, we are arguing in favor of education as a civilizing force. To see education as this force for good, some thought must be given to how a Catholic Curriculum would respond to modern demands for increased layers of accountability, structured training for educational leadership, and the creeping micro-management of schools.

For a Catholic curriculum, education is a preparation for life, not just for paid employment. This vision involves both the training in skills needed for societal utility but also proposes a clear vision of leisure, properly understood, as essential for human development. For the philosopher Josef Pieper, a "leisurely" approach to human life and employment is neither a call to disengagement from working life with its patterns and obligations nor an advocacy of a loosened attachment to hard work; on the contrary, it is a call to move away from an overly technicist approach and thus allow leisure to be the "basis of culture" (Pieper, 2009). Pieper's radical call for leisure is not without practical difficulties. Given the numbers of stakeholders who have an interest in the outcomes of schooling, does the mention of "leisure" not suggest an overly bohemian and carefree approach to education? How can we deal with this?

The Catholic Curriculum implies an authentic otium - the freedom to study and work in leisure, far from the servility imposed by overbearing educational bureaucracies, contemporary dataveillance, and micro-managed curricular packages and accountability. This is a necessary 
corrective to theories of education that place a lopsided emphasis on skills deemed necessary for work and related government and NGO-inspired educational ideologies; these, under the guise of frequently "progressive" principles, make it increasingly difficult for Catholic educational institutions to offer a coherent, faith-filled vision of the human person.

Leisure in this case is not about idleness. It is about attention, or what is increasingly recognized in philosophy of education as the "affective turn" in learning and teaching (Robinson \& Kutner, 2019): fashioning a space where the integrity of the educational moment is not instrumentalized for external purposes, nor calculated purely as another expression of human labor. Neither is this philosophy of leisure merely a call to "return" to Arcadian visions of education as the prerogative of the "well-to-do," spending their days reading and debating with no pressing need to earn a living. Similarly, it cannot be a call, as Aristotle noted in Politics, simply to embrace "amusement" (Book VIII, Part III). An authentic Catholic anthropology sees all human work as a way to sanctity, not as chains to be shed. This much is clear from the importance placed on work from the book of Genesis to Vatican II's teaching on the role of the lay person in society as one called to "infuse the Christian spirit into the mentality and behavior, laws and structures of the community in which one lives" (Second Vatican Council, 1965, 13). There is, therefore, no place in the Christian worldview for a denial of the value of work and its possibilities for human development.

Education as an expression of leisure, however, reproaches an apparent and growing servility in the technocratic era which reduces the human person-in this case the educator and studentto mere digital cogs in either a vast ideological apparatus or as a coerced participant in a project of what Pope Francis has described as "ideological colonization" (Martín, 2017). It asserts, by contrast, a desire to see education as a way to flourish as a human being and, crucially, a related refusal to package educational initiatives in overly utilitarian wrapping. This way of thinking eschews the sense of the human person exclusively as a "worker" in favor of a vision of "a happy and cheerful affirmation of his [sic] own being" (Pieper, 2009, p. 45). Education as a leisurely pursuit hence sees value not in learning "for its own sake," but in proposing deliberative scholarly activity as the search for virtue and good character: The free association of people whose minds wander across the centuries and across cultures in search of the good, the true, and the beautiful as the foundations of a just and flourishing society. This contribution to the educational common good echoes key features of Matthew Arnold's important claim that the purpose of education is "[t]o recommend culture as the great help out of our present difficulties; culture being a pursuit of our total perfection by means of getting to know, on all the matters which most concern us, the best which has been thought and said in the world" (2006, p. 5). While we would not share Arnold's materialism, nor his desire to see culture and education replace a lost religion, we do share his love of heritage and tradition as sources of human sustenance and renewal.

The search for virtue is intrinsic to the liberal underpinning of the Catholic Curriculum. This is 
not without its challenges, since the call to liberal education is not self-evident as an articulation of the Catholic Curriculum. The theology of the Incarnation reminds all Christians that there is such a thing as Truth: Education is the ongoing discovery of that Truth, not a call to construct meaning from a random exploration of educational and cultural novelties. To this noble end (the discovery of Truth), the Catholic Curriculum forges a path through inherited knowledge and invites all to be part of the journey.

\section{Curriculum as Journey}

The origins of the word "curriculum" reside in formulations and descriptions of the programs of study at early modern universities in Scotland and the Netherlands. Indeed, the first Englishlanguage source originated in the conferral ceremonies of the University of Glasgow around the early 1630 s (Hamilton, 1989). At the same time, the terminology migrated to the usages of the University's feeder school, the High School of Glasgow. In both contexts, and for equally unclear reasons, the metaphoric resonance of the term lay with the imagery of the chariot race-a circuit the completion of which required discipline, endurance, and knowledge. We surmise here that this recourse to the imagery of the circus race is rooted in the Reformation reassertion of the Pauline imagery of athletic triumph and the struggle and competition to excel individually in the virtues of the Christian life. It of course needs to be recognized that, even in such progress around the athletics field or the chariot race, we are dealing not only with repetition but with progression and advancement; not only with recurrence but forward narrative momentum to a desired destination: the laurel crown of achievement and reward. The fact that these two vectors run through the idea of the curriculum allows us to see in its necessary repetitions an incremental growth and a preservation of the concept of journey through the familiar and the unfamiliar.

Since the Renaissance, there have been multiple models of this curricular experience, from Comenius through Arnauld, to the Jansenist schools of Port-Royale and the subsequent achievements of the Jesuit syllabi of the $19^{\text {th }}$ century (Davis et al., 2020; Horlacher, 2017). A commonplace perception of these developments, seeing unity amidst their diversity, is to understand them as versions of a spiral curriculum. The spiral is a modern metaphor in this context but nevertheless captures an ancient classical idea that the learner journey is both cyclic and progressive, accumulating enhanced knowledge and understanding through an iterative revisiting and enlargement of the disciplinary traditions. The individual learner, whose growth in all other senses is essentially linear and quantitative, is supported and shaped by rediscovery of the familiar

made new by the encounter with more advanced, complex, and demanding ideas-including, as the learner matures, ideas generated and produced by the learner herself.

To the Catholic mind, the fundamental features of these constructs of the curriculum should be perfectly recognizable. This might be in large measure the result of the Catholic influence on 
how such early models of curriculum planning were devised and realized. However, there is also a significant degree of congruence between these visions of the curriculum and the larger patterns of Christian life. It is in the structure and shape of the Liturgical Year, for example, with its procession of feasts and fasts and its ongoing revisiting in prayer of the essential moments of the Gospel cycle, that we find the symmetry and parallels between the curriculum and liturgy. This leads to the recognition that the curriculum is a sanctified space, which both draws from and is informed by the vision of reality cherished in the celebration of the liturgy.

\section{Liturgy and Curriculum: The Journey to Wholeness}

Saint Paul's Second Letter to Timothy reminds him (and us) to "follow the pattern of the sound words which you have heard from me". Is it possible to see therein a template for a curricular approach which is rooted in tradition and simultaneously open to new developments? The short quotation from Paul reminds us of the crucial role played by the teacher as the human link between tradition, the present, and the future. The importance given to the "pattern of the sound words" suggests a harmony of words and, by implication, metaphors and images. It was this devotion to attentiveness, pattern, tradition, and faithful transmission that supported the first Christians in their attempts to devise an educational process for would-be Christians (catechumens), which was liturgically focused in its orientation toward baptism at Easter. In other words, the first example of the Catholic Curriculum, so to speak, was a liturgical phenomenon.

Maria Harris has explicitly linked Church and curriculum in her book Fashion Me a People: Curriculum in the Church (1989). For Harris, curriculum theory in the Catholic school has five major themes: Koinonia-the curriculum of community; Leiturgia-the curriculum of prayer; Didache-the curriculum of teaching; Kerygma-the curriculum of proclamation; and Diakoniathe curriculum of service. The interaction of these approaches offers schools and educators many tools for reform. We suggest that the five themes proposed by Harris are essential for those keen to develop a Catholic understanding of curriculum from a strong liturgical foundation. Earlier, we proposed that viewing the school curriculum through the lenses of imagination, knowledge, and action was a worthy way of allowing the Catholic intellectual tradition to set the pace of reform. Aligning this trio of lenses with the schema developed by Harris would be, we suggest, a suitable starting-point for educational institutions intent on meaningful curriculum renewal from a Catholic perspective.

Further support for the liturgical underpinnings of a Catholic Curriculum can be found in the history of Catholic education. While the historical record offers multiple examples of early Christian education processes, there can be little doubt that it was firmly rooted in the public worship (liturgy) of the Christian community (Murphy, 2006). Central to this reality was the focus by the early 
Table 1

\begin{tabular}{lll}
\hline Curriculum Theme (Harris) & Curriculum Focus (Harris) & Curriculum Lens \\
Koinonia & Community & Imagination \\
Leiturgia & Prayer & Imagination \\
Didache & Teaching & Knowledge \\
Kerygma & Proclamation & Action \\
Diakonia & Service & Action \\
\hline
\end{tabular}

Church on baptismal and mystagogical catechetical initiatives (Yarnold, 1997). For the $20^{\text {th }}$ century catechetical reformer Josef Jungmann (1962), these vibrant early catechetical methods were essential counterbalances to what he saw as the arid and educationally regressive neo-Scholasticism of the texts used in post-Reformation religious tracts. A rejuvenated catechesis needed, he argued, to refresh itself at the sources found in the early days of Christianity. While Jungmann's ideas do sometimes run close to an idolization of the life of the early Church, we find in his proposals a focus on joyful response to the Kerygma which, he claimed, had been lost amidst a methodological preference for studying dry tomes of questions and answers.

A key intersection in any exploration of the educational possibilities afforded by serious study of Catholic liturgical traditions lies in the work of the German theologian, Romano Guardini. In The Spirit of the Liturgy, first published in English in 1930, Guardini notes that liturgy "is a school of religious training" and offers a "cultural formation of the most lofty and elevated kind" (Guardini, 1930, p. 47). The importance of this short book cannot be underestimated: It is here that we find sketched out the powerful ideas, concepts, and challenges which would underpin the work of the Second Vatican Council and encourage Joseph Ratzinger to use the same title for his own volume on liturgy (Ratzinger, 2018). Guardini is doing more than simply aiming to reform how we see liturgy; he is actually proposing a real participation in the liturgical rites so that the congregation can no longer view themselves as spectators at a ceremony carried out by clergy, but as active participants who are formed through the very act of worship.

For Guardini, the concept of liturgical participation was primarily internal and thus directed toward formation of the heart. In line with Guardini's proposal, the Italian educator Maria Montessori had little doubt that liturgy, properly understood, was an effective pedagogical method which "makes the various acts of the religion real, makes them come to life" (Montessori, 1965, p. 22). Her contribution to religious education is easy to forget, given her deserved place in the canon of contemporary modern education theorists. For Montessori, absorption in both the grand details and minutiae of the liturgy-cycles, movements, and actions-offered the child new educational horizons without moving him/her from the normal place of schooling. She also noted that the 
child's participation in the Sunday liturgy should be free from adult-directed instruction because such overbearing layers of command thwarted the child's potential to participate fully as a child in the liturgical rites (Montessori, 1932). Of course, it is worth bearing in mind that for Montessori's method to be effective in religious education, it needs the availability of liturgical experiences which are strong in sensory stimulation and thus attract learners through the five senses to experience the mystery, grandeur, and closeness of God.

We see in Montessori's work a curriculum centered on the liturgy. It is designed to promote authentic participation in the life of the Church and in the life of the classroom. Furthermore, Montessori also manages to bring together a love of the liturgy with a commitment to practices from popular piety, such as the rosary, stations of the cross, devotion to the Sacred Heart; in doing so, it avoids an unfortunate (and still common) dichotomy which could easily remove liturgy from its position as the primary expression of faith (Congregation for Divine Worship and the Discipline of the Sacraments, 2001, no. 5).

Writing in 1937, Gerard Meath, O.P., lauded Montessori's contribution to liturgical and educational reform. He added to this praise an appreciation of phenomena such as the Dialogue Mass and congregational singing (themselves fruits of the incipient "Liturgical Movement," which was close to the contemporaneous catechetical reform movement); moreover, he proposed that genuine love of liturgy meant that liturgy is something to be lived, not simply learned (Meath, 1937). In both Montessori and Meath, we can discern how the liturgical movement was shaping both catechetical and educational reform and thus allowing the curriculum to gain deeper understanding through active participation in knowledge-rich classroom activities.

\section{Concluding Comments}

In this article, we have argued for a rediscovery of the Catholic Curriculum as a way to refresh the life of the Catholic school, currently facing countless challenges from so-called progressive and secularist thinking. It is neither a raising of the religious drawbridge to keep apparently hostile ideas at a distance nor a vision of education which is suitable only for those who belong to the Catholic religious tradition. It is, rather, a significant contribution to public dialogue on pedagogy, as it seeks to articulate an educational framework which values knowledge, tradition, and community over the decontextualized generic skills and criterion-based "outcomes" of the technocratic curriculum. Given the decline in the educational influence of the religious orders and teaching congregations, much of the memory of Catholic education is in danger of falling into unfortunate desuetude (Fitzpatrick, 2019; Rymarz \& Franchi, 2019). As a counter to this sociological and religious reality, there is a pressing need to recapture and refresh the charisms found in such orders and congregations by suitably weaving their insights through contemporary programs of Catholic teacher formation-both for future and for current teachers. 
To explore critically the shape and contours of the Catholic Curriculum is one way of reenergizing the Catholic educational community to move forward confidently, constructing fresh pathways through the secular educational landscapes and, ideally, offering hope-filled initiatives for the greater good of society.

\section{References}

Aristotle (350 B.C.E.). Politics. Retrieved from

http://classics.mit.edu/Aristotle/politics.8.eight.html

Arnold, M. (2006). Culture and Anarchy. Oxford University Press.

Arthur, J., \& Walsh, P. (2007). Can there be a Catholic School Curriculum? Renewing the debate.

Centre for Research and Development in Catholic Education.

Augustine (1995). The teacher. In against the academicians and the teacher (P. King, Trans.), 97-145. Hackett.

Benedict XVI. (2011). Video message to the court of the gentiles. Retrieved from https://www.vatican.va/content/benedict-xvi/en/messages/pont-messages/2011/documents/ hf_ben-xvi_mes_20110325_parvis-gentils.html

Blake, N., Smeyers, P., Smith, R., \& Standish, P. (1998). Thinking again: Education after postmodernism. Bergin \& Garvey.

Cole, M. (2017). Education, equality and human rights: Issues of gender, "race," sexuality, disability and social Class (4th ed). Routledge.

Congregation for Catholic Education. (1988). The religious dimension of education in the Catholic school. Retrieved from http://www.vatican.va/roman_curia/congregations/ccatheduc/ documents/rc_con_ccatheduc_doc_19880407_catholic-school_en.html

Congregation for Catholic Education. (2013). Educating to intercultural dialogue in Catholic schools: Living in hope for a civilization of love. Retrieved from http://www.vatican.va/roman_curia/congregations/ccatheduc/documents/rc_con_ccatheduc_ doc_20131028_dialogo-interculturale_en.html

Congregation for Divine Worship and the Discipline of the Sacraments. (2001). Directory on popular piety and the liturgy. Retrieved from http://www.vatican.va/roman_curia/ congregations/ccdds/documents/rc_con_ccdds_doc_20020513_vers-direttorio_en.html

Darling-Hammond, L. (2017). Teacher education around the world: What can we learn from international practice? European Journal of Teacher Education, 4O(3), 291-309. https://doi.org/10.1080/02619768.2017.1315399

Davis, R.A. (1999). Can there be a Catholic Curriculum? In Conroy, J.C. (Ed.), Catholic education inside out/outside in (pp. 207-230). Lindisfarne Books.

Davis, R.A., Conroy, J.C., \& Clague, J. (2020). Schools as Factories: The Limits of a Metaphor. 
Journal of Philosophy of Education, 54(4), 1471-1488. https://doi.org/10.1111/1467-9752.12525

Davis, R.A., \& Franchi, L. (2013). A Catholic curriculum for the twenty-first century? International Studies in Catholic Education, 5(1), 36-52. https://doi.org/10.1080/19422539.2012.754587

Fitzpatrick, C. (2019). It's More than Just Religion: Teaching History in a Catholic School. Journal of Catholic Education, 22(1). Retrieved from https://digitalcommons.lmu.edu/ce/vol22/iss1/22

Franchi, L., Convery, J., \& Valero, J. (2021). Reclaiming the piazza III: Communicating Catholic culture. Gracewing.

Francis (2014). Address to participants in the plenary session of the Congregation for Catholic Education and Educational Institutions. Retrieved from http://w2.vatican.va/content/francesco/en/speeches/2014/february/documents/papafrancesco_20140213_congregazione-educazione-cattolica.html

Guardini, R. (1930). The spirit of the liturgy. Crossroads Publishing Company. Hamilton, D. (1989). Towards a theory of schooling. The Falmer Press.

Harris, M. (1989). Fashion me a people: Curriculum in the Church. Westminster/John Knox Press. Horlacher, R. (2017). The same but different: the German Lehrplan and curriculum. Journal of Curriculum Studies, 5o(1), 1-16. https://doi.org/10.1080/00220272.2017.1307458

Jungmann, J. (1962). The good news and yesterday. Sadlier Inc.

Kadir, M.A.A. (2017). What teacher knowledge matters in effectively developing critical thinkers in the 21st century curriculum? Thinking Skills and Creativity, 23, 79-90. https://doi.org/10.1016/j.tsc.2016.10.011

Kitchen, W.H. (2017). Philosophical reflections on neuroscience and education. Bloomsbury.

Martín, I.S. (2017). Pope Francis: Ideological colonization “a blasphemy against God.” Crux. Retrieved from https:

//cruxnow.com/vatican/2017/11/21/pope-francis-ideological-colonization-blasphemy-god/

McDonough, G.P. (2018). The Joy of Dialogue in an Intercultural World: Educational Implications from Evangelii Gaudium. Annual Review of the Sociology of Religion, 9, 222-246. https://doi.org/10.1163/9789004380073_013

McLaughlin, T. (2002). A Catholic Perspective on Education. Journal of Education and Christian Belief, 6(2), 121-134. https://doi.org/10.1177/205699710200600205

Meath, G. (1937). Liturgical education. New Blackfriars, 18(210), 666-673.

Montessori, M. (1932). The Mass explained to children. Sheed and Ward.

Montessori, M. (1965). The child in the Church. Catechetical Guild.

Murphy, D.D. (2006). Teaching that transforms: Worship as the heart of Christian education. Wipf \& Stock.

Organisation for Economic Co-operation and Development. (2020). Taking stock of the present: Trends in education and schooling. In Back to the future of education: Four OECD scenarios for 
schooling. OECD Publishing.

Padelford, F.M. (1902). Address to young men on the right use of Greek literature. In Essays on the study and use of poetry by Plutarch and Basil the Great (pp. 99-120). Lamson, Wolffe and Company. Retrieved from http://www.earlychristianwritings.com/fathers/basil_litteratureo1.html

Pieper, J. (2009). Leisure: The basis of culture. Ignatius Press.

Priestley, M., Philippou, S., Alvunger, D., \& Soini, T. (2021). Curriculum making: A conceptual framing. In Priestley, M., Alvunger, D., Philippou, S., \& Soini, T. (Eds.), Curriculum making in Europe: Policy and practice within and across diverse contexts (pp. 1-28). Emerald Publishing Limited.

Ratzinger, J. (2018). The spirit of the liturgy. Ignatius Press.

Rausch, T. (2012). Catholic anthropology. In Piderit, J., \& Morey, M. (Eds.), Teaching the tradition: Catholic themes in academic disciplines. 31-46. Oxford University Press.

Robinson, B., \& Kutner, M. (2019). Spinoza and the affective turn: A return to the philosophical origins of affect. Qualitative Inquiry, 25(2), 111-117. https://doi.org/10.1177/1077800418786312

Royal, R. (2015). A deeper vision: The Catholic intellectual tradition in the twentieth century. Ignatius Press.

Rymarz, R., \& Franchi, L. (2019). Catholic teacher preparation: Historical and contemporary perspectives on preparing for mission. Emerald.

Second Vatican Council. (1965). Decree on the apostolate of the laity “Apostolicam Actuositatem.”. Retrieved from http://www.vatican.va/archive/hist_councils/ii_vatican_council/documents/ vat-ii_decree_19651118_apostolicam-actuositatem_en.html

Sturgeon, N. (2018). The First Minister's tribute to the life and the legacy of the late Cardinal Thomas Winning. Retrieved from https://www.gov.scot/publications/cardinal-winning-lecture/ Sullivan, J. (2001). Catholic education: Distinctive and inclusive. Kluwer Academic Publishers. Takaya, K. (2018). Caroline Pratt's Idea of Curriculum and Imagination. Interchange, 49(2), 205-216. https://doi.org/10.1007/s10780-018-9322-9

Warren, L.L. (2021). The importance of teacher leadership skills in the classroom. Education Journal, 1o(1), 8-15. https://doi.org/10.11648/j.edu.20211001.12

Yarnold, E. (1997). Baptismal catechesis. In Jones, C., Wainwright, G., Yarnold, E., \& Bradshaw, P. (Eds.), The study of liturgy. 91-95. Oxford University Press. 